\title{
THE LIMITS OF CONVERGENCE IN LANGUAGE CONTACT
}

\author{
Carmen Silva-Corvalán \\ University of Southern California
}

\section{Introduction}

This article discusses the contact situation between English and Spanish in the USA, a situation characterized by both maintenance of the minority language and shift to English. Of relevance to understanding the linguistic phenomena that develop in this situation of societal bilingualism is the fact that the minority language is constantly being revitalized by interaction with large groups of immigrants from Spanish-speaking countries.

In this context of societal bilingualism an oral proficiency continuum develops in the two languages, either as a result of incomplete learning of the minority language or its attrition due to restricted exposure to and use of this language. The continuum ranges from standard or unrestricted Spanish to an emblematic use of Spanish and, vice versa, from unrestricted to emblematic English. At the individual level, the continuum reveals dynamic levels of proficiency in the subordinate language and different degrees of convergence with English. Speakers can be located at various points along this continuum, but it is in principle possible for an individual to move or be moving toward (hence 'dynamic' level) one or the other end of the continuum at any given synchronic stage of his life. This is a fluid situation that may give rise to both borrowing and imposition by the same agents of transfer at different times throughout their lives (see discussion of these terms in Winford, 2007).

The 2000 Census indicated that the population of the USA was close to three hundred million (US Bureau of the Census, 2005). Of these, over thirty-five million were Hispanics. About sixty percent of the Hispanic (or Latino) population resides in the five states referred to as "the Southwest": New Mexico, Texas, California, Arizona, and Colorado. It is estimated that by the year 2010 Hispanics will be the nation's largest minority ethnic group (13.8\%) and by 2050 they will compose twenty-five percent of an estimated total population close to four hundred million (Day, 1996). The Hispanic group would add the largest number of people to the population of the USA because of higher fertility rates and, importantly for a linguistic perspective, net immigration levels. The predicted growth in the size of the Hispanic population does not necessarily project a corresponding percentage growth in the number of speakers of Spanish, however, since once settled in the USA the shift to English is massive. 
Unlike the Northeast, the Hispanic population of the Southwest dates back to the sixteenth century, when the earliest expeditions of Spaniards from Mexico came to the region. Colonial Spanish has given way to contemporary varieties of Spanish, however, brought by immigrants who have come mainly from Mexico. The expanding Hispanic population's ties with family, friends, and business associates in Latin America constantly revitalize the Spanish language, and bodes well for the maintenance of Spanish as a strong societal language in the United States.

The Spanish of US-born Hispanics is characterized by phenomena typical of a situation of intensive and extensive bilingualism: grammatical and lexical simplification, intensive lexical borrowing (and imposition) from English, and code-switching, i.e., alternating between Spanish and English in the same conversational turn or across turns.

It is frequently argued that in the situation described a new language is emerging in the USA, Spanglish, a mixture of Spanish and English. Examples such as those in (1) and (2), where speakers smoothly switch between the two languages, are given in support of such proposal:

(1) Un mecánico mexicano le dijo una a la - al que está cocinando en el catering wagon, le dijo una de doble sentido, una palabra de doble sentido nomás. Nothing serious, nothing serious, you know, just a- No me acuerdo qué era ni nada. So le hablé yo p'atrás en español. 'Ya te agarré la movida', le dije, 'Ya te, ya te estoy escuchando'.

'A Mexican mechanic said one to the- to the one who's cooking in the catering wagon, he told him a double sense one, just one double sense word. Nothing serious, nothing serious, you know, just a- I don't remember what it was. So I talked back to him in Spanish. "I got what you said", I said, "I'm, I'm listening to you".'

(2) They were laying off. So, I didn't get laid off. Ramón, Ramón got laid off. And I quit because he got laid off. Because I was working, and he was working at nights. --- Dije, 'No, si lo van a descansar a él, ¿pa' qué me quedo yo, especial yo?' Yo, de aquí, como, 'onde puedo agarrar trabajo. El, es más difícil, porque he's not 'reglado' para 'garrar trabajo.

'I said, "No, if they're going to lay him off, why should I stay, especially me?" I'm from here, so I can get a job anywhere. As for him, it's more difficult, because he's not 'fixed' (legalized) to get a job.'

Examples (1) and (2) are from speakers whose grandparents came from Mexico and in whose homes the main language of communication is English (I refer to them as "group 3" or G3). Note, however, that even in this situation of reduced exposure to and use of Spanish the segments of speech in this language preserve its structure and do not replicate that of the dominant language, English. Indeed, note the retention of typological features foreign to English: the order N-Adj (mecánico mexicano 'Mexican mechanic'), the preverbal dative pronoun (le dijo '(he) told him'), null subjects (No me acuerdo '(I) don't remember'), the order VS (le hablé yo 'I spoke to him'). I will argue, therefore, that in the process of shifting from Spanish to English at the societal level, and under the cognitive and social pressure from a dominant language at the individual level, speakers do not modify the abstract syntactic structure of the receding language; syntax is, it seems, the limit of convergence.

\section{Is syntax "borrowable"?}

My goal in this paper is to present arguments and evidence from a number of contact situations in support of the view that the transfer of features from one language to another does not involve 
syntax, but lexicon and pragmatics. I will also demonstrate that this type of interlanguage transfer is constrained by the structure of the recipient language, and by general cognitive principles. Thus, although it may not be possible to predict that a specific change will occur in a recipient language, it may be possible to delimit, on the basis of general principles, the nature of the changes and constraints on their occurrence, given certain specific sociolinguistic conditions.

Making the argument that syntax is not transferred involves the difficulty of having to define "syntax" since a given phenomenon may be considered to be syntactic by some, but others may view it as lexical-semantic (e.g., verb subcategorization, selectional restrictions) or morphological (e.g., clitic pronoun usage, gender agreement). My hypothesis is based on a structuralist definition of syntax which distinguishes two levels (Gutiérrez Ordóñez 1997): an abstract structural level in which functions are simply empty slots with no lexical entries, as in (3); and a concrete level with lexical entries which needs to consider semantic well formedness, as in (4 a \& b). Observe that while (4 a) is semantically appropriate, $(4 \mathrm{~b})$ is not because an inanimate entity cannot perform the action of buying.

\section{Abstract syntactic structure \\ (3) subject verb direct object NP $\quad \mathrm{N} \quad \mathrm{NP}$ \\ Concrete syntactic structure \\ (4) a. The hamburger dirtied the plate. \\ b. *The hamburger bought mayonnaise.}

I will show that transfer occurs at the level of concrete syntax, through lexical units or phrases used in situated acts of communication, and does not affect the basic syntactic typology of the recipient language. The locus of transfer is the bilingual individual. The diffusion of transfer is a social phenomenon. Individuals transfer lexical items and pragmatic uses from English (the source language) and these may eventually lead to syntactic change at the concrete level. Change in the recipient language (Spanish) occurs when an innovation has spread to a community of speakers, i.e. at the societal level (cf. Weinreich, Labov \& Herzog 1968). Lexical items, subcategorizations, discourse constraints and pragmatic uses modelled after the source language may gradually permeate an individual's grammar and gradually spread across individuals, resulting eventually in crystallized fixed patterns characteristic of the language used in a community. The innovative element is part of a linguistic system; therefore, it gradually expands its distribution and generalizes to other elements. Every innovative pattern at every stage of diffusion, however, is compatible with the basic typology of the recipient language and enters it through the existence of closely parallel constructions. Similar hypotheses have been defended by a number of authors (e.g., King 2000; Landa 1995, 2000; Louden 1997; Prince 1992; Weinreich 1974).

In a situation of extensive and intensive bilingualism, bilinguals are called upon to communicate often in one language or the other in rapid succession in response to different interlocutors, different social domains, or other factors. The need to lessen the cognitive effort that this task demands may explain in part the typical processes of regularization, the loss of infrequently used constructions, and the conscious or unconscious preferential use of parallel concrete structures in the languages involved, a phenomenon that leads to convergence. This outcome is widely attested in the literature (e.g., Campbell 1987; Dorian 1989; Landa 1995; Martineau 1988; Nadkarni 1975; Prince 1992; Silva-Corvalán 1994). Under conditions of intensive and extensive bilingualism, it seems logical to expect that frequently used patterns in the socially dominant language will motivate an increase in the frequency of use of parallel structures in the subordinate language, and that frequently used patterns within this language will also tend to become extended. This implies a certain degree of 
simplification and loss of structures in the subordinate language and a gradual move towards crosslinguistic convergence.

Cognitive and linguistic considerations, then, may allow us to predict the nature of at least some of the types of change that may or may not occur, and the constraints on their occurrence. In earlier work (Silva-Corvalán 1994, 1998), I demonstrated the type of influence that English has had on the Spanish spoken in Los Angeles (L.A.). There, indirect influence was evident in the preferential use of parallel structures, and in the gradual loss of discourse-pragmatic constraints not present in English. But in L.A. Spanish there was no obvious evidence of changes in the typological patterns of Spanish.

Consider at this point some of the results of this previous research, in particular those concerning null elements and word order.

\section{Spanish in contact with English}

\subsection{Expressed and null subjects, and placement of expressed subjects}

In earlier work (Silva-Corvalán 1994) I examined the possibility that Spanish might develop rules of obligatory subject expression and categorical preverbal placement of subjects. Qualitative and quantitative analyses, however, indicated a trend toward fewer expressed subjects among bilinguals born in the USA (Groups 2 and 3), ${ }^{1}$ which I interpret as a sign of gradual loss of pragmatic functions associated with the expression of subjects. I also ascertained that English-dominant bilinguals show higher percentages of preverbal subjects with unaccusative verbs (ex. 5 a), which usually introduce new entities into discourse and are expected to be placed postverbally in Spanish not in contact with English (General Spanish).

(5) a. Estaban peleando y entonces la policía llegó. (Group 2)

'They were fighting and then the police came.'

b. Estaban peleando y entonces llegó la policía. (General Spanish)

English is a strict SVO language that requires the expression of a grammatical subject. Thus, the fact that L.A. Spanish evidences a lower frequency of subject expression and a higher frequency of preverbal subjects (SV order) is incompatible with a hypothesis of direct syntactic influence from English, even if syntax were to be defined as form plus meaning or discourse function. More adequate explanations are found instead by positing the loss of discourse-pragmatic constraints. Indeed, group 2 and 3 speakers may be less sensitive to the pragmatic rule that motivates the placement of new information subjects in postverbal position in Spanish (as in $5 \mathrm{~b}$ ). Likewise, they may generalize the option of a non-expressed subject to discourse contexts which would favor it, e.g., when the referent is being established as the topic of a discourse passage.

\subsection{Null complementizer/relative pronoun que 'that'}

English has the possibility of a zero complementizer in relative and complement clauses, as in (6 a), while Spanish disallows them in the parallel structure $(6 \mathrm{~b})$.

(6) a. She told me (0) she was delighted with the vase (0) she had just bought.

b. (Ella) me dijo *(que) (ella) estaba feliz con el jarrón *(que) (ella) había comprado.

\footnotetext{
${ }^{1}$ I differentiated three groups of speakers. Briefly, Group 1, immigrants from Mexico after age 11 (Spanish dominant); Group 2, speakers born in the USA whose parents had come from Mexico (English dominant); Group 3, speakers born in the USA whose grandparents had come from Mexico (English dominant).
} 
English-dominant bilinguals in L.A. produce Spanish sentences with a null complementizer in complement clauses $(7$ a) but not in relative clauses $(7 \mathrm{~b})$.

(7) a. Yo creo 0 inventaron el nombre que le pusieron. (Group 2)

'I believe 0 they invented the name that they gave her.'

Importantly, omission of que 'that' in complements is allowed in formal or written registers of General Spanish (Subirats-Rüggeberg 1987), but not in relative clauses. In addition, null que is attested in the informal oral mode of some varieties of Eastern Mexican Spanish, which may explain its occurrence in group 1 immigrants. Its extension to or retention in conversational Spanish may have been favored in Mexico by the fact that some indigenous languages do not require a free subordinator in complement clauses (Hekking \& Muysken 1995), and in L.A. by contact with English. But the structure of Spanish constrains this transfer to occur only in complement clauses of request and estimative verbs like creer 'to believe', pensar 'to think', and saber 'to know'.

English may have had a similar indirect influence on que deletion in Canadian French, where deletion is attested fairly frequently in complement clauses of such verbs as penser 'to think', dire 'to say', savoir 'to know', croire 'to believe' (Martineau 1993) (ex. 8), but it also occurs, with lower frequencies, in circumstantial and relative clauses, as shown in examples (9) and (10), taken from Martineau (1988).

(8) Je pense que / 0 c'est ça.

'I think that / 0 it's that'.

(9) C'est ça que / 0 je dis.

'That's what I say'.

(10) C'est parce que / 0 tu veux.

'It's because you want to'.

Complementizer deletion in Canadian French most probably results from the retention and gradual generalization of a construction which is reported as frequent in historical grammars until the period of Classical French (Foulet 1977:333). Note, furthermore, that deletion has also been retained in modern varieties of popular French in France (Martineau 1993:81).

In L.A. Spanish and in Canadian French, then, deletion of que has firm roots in the parent non-English contact dialects. The restriction in L.A. Spanish to a type of complement clause where other Spanish registers also allow zero que argues in favor of constraints on syntactic change due to contact: in its early stages, change is evident in the more frequent use of a parallel structure. This, in time, may open the door to further changes and restructuring which would be constrained by the structure of the language itself.

\subsection{Lexico-syntactic calques}

Further doors to change are opened by what I call "lexico-syntactic calques". In these cases, an English word or an English "expression" (in the technical sense of the word, cf. Tomasello, 2003:100) is matched up with a Spanish word or expression. The word in the receiving language may incorporate semantic components, as well as subcategorization and selectional restrictions from English, but it must originally share some semantic or pragmatic component with the corresponding element in the contact language.

Transfer starts with the calquing of concrete structures in situated acts of communication, but in time the lexical units affected may change their semantic features and their possibilities of cooccurrence beyond the specific construction which was originally transferred. Indeed, if novel ways 
of putting words together, usually constituting semantic extensions, come into a language through transfer, they may eventually become fixed in (concrete) syntax (cf. García 1995:53), in the sense that they become mechanical and habitual in a speech community (Otheguy 1995).

Consider examples (11) and (12) from Los Angeles Spanish. In Spanish, the interrogative adverb of manner cómo does not have the meaning of 'to what extent, amount, or degree' as how may have in English. As indicated in the General Spanish (Gen.Span.) versions, questions which ask about the extent to which something is or was liked, as in ex. (11), should not include the interrogative word cómo, since cómo-questions must be answered with a description of the manner in which the situation obtains, as in (12). Yet ex. (11 a) and the answer in (11 b) are attested in L.A. Spanish.

a.: Y tu carro que compraste, ¿cómo te gusta? (Group 2)

lit.: and your car that (you) bought, how to-you pleases?

Gen. Span.: Y el carro que compraste, ¿te gusta?

lit.: and the car that (you) bought, to-you pleases?

'And the car you bought, how do you like it?'

b.: Mi carro me encanta. (Group 2)

'I love my car.'

* Me gusta amplio.

*'I like it spacious.'

(12) Gen. Span.: a. ¿Cómo te gusta el café? 'How do you like coffee?'

b. Me gusta cargado.

'I like it strong.'

Example (12) shows that the concrete syntactic structure cómo X gustar $Y$ exists in Spanish and has not been transferred from the parallel English construction. What has been transferred from English is the possibility of using the construction to ask about the extent to which something or someone is liked. This new usage may affect the meaning of the question adverb cómo, which did not have the component "to what extent" but may now be used with this sense. Note, however, that the inference of "to a great extent" was possible in a type of rather infrequent exclamation in Spanish, illustrated in ex. $13,{ }^{2}$ which could be inferred to communicate that the speaker likes something a great deal. Thus, examples of the type of (11) constitute a new pragmatic use, a new expression, and not an innovation at the abstract level of syntactic structure.

(13) ¡Cómo me gustan los churros con chocolate!

'How I like churros with chocolate!'

The distribution of how is transferred as well to a declarative context, namely to the complement of saber 'to know'. Here again, Spanish cómo in the complement of saber 'to know' refers to the manner of a specific situation, as in ex. (14 a), which could be appropriately followed up by instructions on 'how to', as in (14 b). Note, however, that the wider meaning of how in English allows it to occur with to know when only a general knowledge or skill required to do something is being referred to, as in ex. (15). While in General Spanish ex. (15) must be translated without cómo 'how', this complementizer is acceptable in L.A. Spanish, as shown by ex. (16).

(14) a. María no sabe cómo irse a la universidad.

'Mary doesn't know how to go to the university.'

${ }^{2}$ I thank Ricardo Otheguy for bringing this fact to my attention. 
b. Dile que tome el bus 73 .

'Tell her to take bus 73.'

(15) He doesn't know how to read yet.

'No sabe $\underline{0}$ leer todavía.'

Sí sabía como hablar español. (Group 3)

lit.: yes knew-3sg how speak-inf Spanish

Gen. Span.: Sí sabía $\underline{0}$ hablar español.

'He did know how to speak Spanish.'

The examples in (11) and (16) represent new cooccurrence patterns or concrete syntactic patterns. Similar cases affect other words and expressions in Spanish, e.g., the word tiempo 'time', as in (17) and (18), the demonstrative este 'this' in the introduction of a new entity in discourse, as in (19) (new-this in English, Wald, 1983).

Es un modo de tener un buen tiempo. ${ }^{3}$ (Group 3)

lit.: (it)'s a way to have a good time

Gen. Span.: Es un modo de pasar un buen rato / pasarlo bien

lit.: (it)'s a way to pass a good moment / pass it well

'It's a way to have a good time.'

... pero cuando llegó el tiempo que ellos ya querían sus carritos... (Group 3)

lit.: but when arrived the time that they already wanted their cars

Gen. Span.: pero cuando llegó el momento que ellos ya querían sus carritos...

lit.: but when arrived the moment that they already wanted their cars

'... but when the time came when they wanted their car ...'

(19) Estábamos en el patio cuando este niño ${ }_{i}$ se me acercó y me empezó a molestar, así que yo lo ${ }_{i}$ empujé y ...' (Group 2)

'We were in the school yard when this boy $y_{i}$ came up to me and started bugging me, so I pushed $\operatorname{him}_{\mathrm{i}}$ and ...'

Gen. Span.: Estábamos en el patio cuando un niño $\underline{i}_{i}$ se me acercó y me empezó a molestar, así que yo $l_{\mathrm{i}}$ empujé y ...'

The word tiempo is quite vulnerable in a Spanish-English contact situation because many but not all the uses of English 'time' overlap with it. This situation most likely favors the extension of tiempo, basically a durative mass concept in Spanish, to incorporate the notion of one specific point: 'one of several instances, an occasion, an hour, a moment' (ex. 18). In Spanish, the phrase buen/mal tiempo (as in ex. 17), in the singular, can only mean 'good/bad weather'.

In all the cases discussed, the word or expression that comes to be used in an innovative way in Spanish shares some component with the corresponding English word or expression, and no change has affected the abstract syntax of Spanish.

To summarize, then, L.A. Spanish evidences an increased frequency of structures that have parallels in English. This increase involves:

\footnotetext{
${ }^{3}$ Note that the abstract structure exists [Prep V DO], and it may be lexically filled as in such parallel example as Es el deseo de tener un buen salario 'It's the desire to have a good salary.'
} 
a) gradual loss of discourse-pragmatic constraints (e.g., affecting word order, and the expression of subjects);

b) gradual loss of register constraints (e.g., complementizer deletion);

c) gradual alteration of selectional restrictions (e.g., affecting como 'how', tiempo 'time').

\section{Beyond Los Angeles}

Consider now some cases of contact between Spanish and languages other than English which are typologically more distant from Spanish.

The old contact situation involving Spanish and Basque, for instance, offers supporting evidence for our general thesis that syntax is the limit of convergence. Despite the intense cultural and linguistic pressures of more than seven hundred years, Basque has remained typologically very different from Spanish: it continues to be an ergative language with OV basic word order. Landa \& Elordui (1999:230) have shown that there has been some interlanguage influence, but this has involved lexical phenomena and the loss of semantic or pragmatic restrictions which have resulted in structures innovative only at the concrete level.

Spanish has had over four centuries of contact with indigenous American languages which have borrowed even so-called "unborrowable" function words (Brody, 1995). But Brody and Hekking \& Muysken (1995) examine a number of these indigenous languages from Mexico to Ecuador and independently argue that these languages have borrowed conjunctions with primarily discourse meanings. ${ }^{4}$ In some cases the borrowings ended up replacing some of the native particles, but at first the conjunctions "nearly always occur along with an indigenous element that fulfills a similar function" (Brody 1995:140).

Hekking \& Muysken (1995) further observe that Otomi, for instance, borrows many more prepositions and conjunctions than Quechua does from Spanish, and surmise that this difference is most likely due to their dissimilar typologies. Otomi, like Spanish, is a right-branching language (VO) while Quechua is left-branching (OV). In Quechua, they affirm that only que 'that' appears to have "a clearly defined grammatical role" (p. 112), while the rest of the borrowings seem to function as "discourse markers". Note, however, that que occurs redundantly with the indigenous subordinator -spa, making que repetitive and grammatically unclear. Consider their example (4), reproduced here as (20):

(20) chanta atoj-taj-ri willasku-spa que pega-mu-sqa

thus fox_ENF_RF say_SUB that hit-CIS-NAR

'Así el zorro diciendo que iba a pegar...'

'Thus the fox saying that he was going to hit ...'

[ENF= emphatic; $\mathrm{RF}=$ referential; $\mathrm{SUB}=$ adverbial subordinator; $\mathrm{CIS}=$ "cislocative"? ("like here"); NAR= narrative tense]

The Quechua construction marks 'to say' with the suffixed Quechua subordinator -spa; que is redundant and precedes a clause that maintains Quechua structure in all other respects. Given a situation of this sort, one may predict, based on the principles of regularity and transparency, that the subordinate language will tend to substitute the free, invariant, and unambiguous marker for the bound and multifunctional Quechua form.

\footnotetext{
4 The conjunctions borrowed include $y$ luego 'and then', como 'like', pues 'because, well...', porque 'because', pero 'but', que 'that', si 'if' and sino que 'but' in various languages.
} 
Justifiably, then, one may conclude that these so-called "grammatical borrowings" are indeed lexical: conjunctions, subordinators, and prepositions that did not affect the syntax of the recipient language when they were transferred. Note the concurrence between Brody's and Hekking \& Muysken's data: in all these situations the subordinating conjunctions borrowed occur redundantly with the indigenous element. Furthermore, Hekking \& Muysken add that the structural differences between Otomi and Quechua appear to explain more appropriately than historical, demographic, and social factors the different ways in which these languages adopt and adapt function-word loans.

\section{Final remarks}

The studies discussed strongly support my proposal that transfer is constrained by the structure of the languages involved, and contradicts the claim that "anything goes" (Campbell \& Muntzel, 1989; Thomason \& Kaufman 1988), at least under some sociolinguistic conditions. There is evidence for lexical transfer, some of which may have syntactic consequences. There is also gradual loss of discourse-pragmatic restrictions as well as incorporation of new uses of existing structures, all of which produce a slight foreign quality, comparable to what happens at the phonetic level.

Many of the studies that have argued for "grammatical borrowing" in contact situations (e.g., Campbell, 1993; Nadkarni, 1975; Gumperz \& Wilson, 1971; Thomason, 1986) have focused mainly on the outcome of centuries-long language contact and lack the critical data to examine the early stages of change. Be that as it may, most of the changes presented correspond to reductions or generalizations, rather than to the incorporation of foreign structures. Let me reassert, however, that mine is not an argument against the existence of externally caused changes. On the contrary, it is impossible to deny the impact that intensive language contact may have, especially on a subordinate language. What I have attempted to show is that every change allowed appears to be constrained by the structure of the affected language.

The effect of this linguistic filter, as it were, may have been what motivated Thomason's statement that "the innovated structure and the source-language structure need NOT be identical...non-identical interference features are common" (1986:245). We may ask ourselves why "non-identical interference features are common". The answer, it seems to me, lies precisely in the fact that what is transferred is NOT a syntactic structure, but the semantics or the pragmatics of a construction, which is then linked to a closely structural parallel in the recipient language. I would like to make the stronger claim that the paired structures need to share at least one element of meaning or one pragmatic function (cf. Prince, 1992), as illustrated in ex. (21).

(21) Se fue pa' atrás pa' México. (Concrete structure B)

'He went back to Mexico.' (Concrete structure A)

Gen. Span.: Regresó a México.

'He returned to Mexico.'

In example (21), the bilingual speaker has established a parallel between (go) back and (ir) para [pa'] atrás, superficially parallel since the structures are not identical: [V Adv] in English, but [V Prep Adv] in Spanish. A and B have corresponding lexical elements with partially equivalent meaning: go = ir in Voy a México 'I go to Mexico', and back = atrás in Está atrás 'It's in the back', but back and atrás do not share the metaphorical extension that includes the concept of repetition or return in English (as in go back, call back, give back, etc.). This meaning is copied onto para atrás, which in General Spanish only has the literal location meaning (pasar $(X)$ para atrás 'pass $(\mathrm{X})$ to the back'). 
This type of contact-induced change may be schematized as in Figure 1.

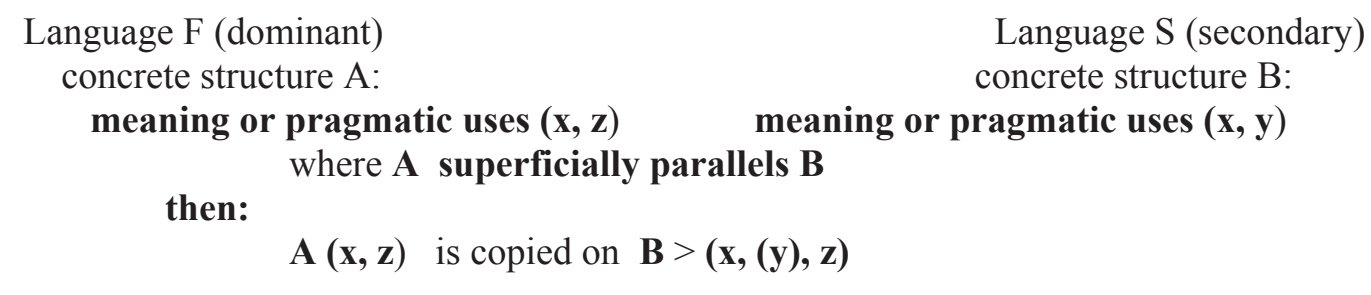

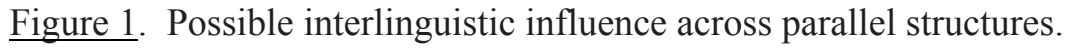

\section{References}

Brody, Jill. 1995. Lending the "unborrowable": Spanish discourse markers in indigenous American languages. In Carmen Silva-Corvalán, Spanish in four continents: Studies in bilingualism and language contact, 132-147. Washington, D.C.: Georgetown University Press.

Campbell, Lyle. 1987. Syntactic change in Pipil. International Journal of American Linguistics 53:253-280.

Campbell, Lyle. 1993. On proposed universals of grammatical borrowing. In Henk Aertsen \& Robert Jeffers, Historical Linguistics 1989, 91-109. Amsterdam: John Benjamins.

Campbell, Lyle \& Martha C. Muntzel. 1989. The structural consequences of language death. In Nancy C. Dorian, Investigating obsolescence, 181-196. Cambridge: Cambridge University Press.

Day, Jennifer C. 1996. Population projections of the United States by age, sex, race, and Hispanic origin: 1995 to 2050. US Bureau of the Census, Current Population Reports, P25-1130. Washington, D.C.: US Government Printing Office.

Dorian, Nancy, ed. 1989. Investigating obsolescence. Cambridge: Cambridge University Press.

Foulet, Lucien. 1977. Petite syntaxe de l'Ancien Français. $13^{\text {th }}$ edition. Paris: Librairie Honoré Champion.

García, Erica. 1995. Frecuencia (relativa) de uso como síntoma de estrategias etnopragmáticas. In Klaus Zimmermann, Lenguas en contacto en Hispanoamérica, 51-72. Frankfurt: Vervuert.

Gumperz, John \& Robert Wilson. 1971. Convergence and creolization. In Dell Hymes, Pidginization and creolization of languages, 151-167. Cambridge: Cambridge University Press.

Gutiérrez Ordóñez, Salvador. 1997. Temas, remas, focos, tópicos y comentarios. Madrid: Arco/Libros. 
Hekking, Ewald \& Pieter Muysken. 1995. Otomí y Quechua: una comparación de los elementos gramaticales prestados del español. In Klaus Zimmermann, Lenguas en contacto en Hispanoamérica, 101-118. Frankfurt: Vervuert.

King, Ruth. 2000. The lexical basis of grammatical borrowing: A Prince Edward Island case study. Amsterdam: John Benjamins.

Landa, Alazne. 1995. Conditions on null objects in Basque Spanish and their relation to leismo and clitic doubling. Ph.D. dissertation, University of Southern California.

Landa, Alazne. 2000. Del paralelismo estructural a la convergencia gramatical: contacto españolvasco. In Annick Englebert, Michel Pierrard, Laurence Rosier \& Dan Van Raemdonck, Actes du XXIIe Congrès de Linguistique et de Philologie Romanes, vol. VI, 285-292. Tübingen/Max Niemeyer Verlag.

Landa, Alazne \& Agurtzane Elordui.1999. Gramáticas en contacto: Condiciones de permeabilidad y tendencias universales. In Angel Yanguas \& Francisco J. Salguero, Estudios de lingüistica descriptiva y comparada, 229-238. Sevilla: Kronos.

Louden, Mark L. 1997. Linguistic structure and sociolinguistic identity in Pennsylvania German society. In James R. Dow \& Michèle Wolff, Languages and lives: Essays in honor of Werner Enninger, 79-91. New York: Peter Lang.

Martineau, Frances. 1988. Variable deletion of que in the spoken French of Ottawa-Hull. In J.P. Montreuil \& D. Birdsong, Advances in Romance Linguistics, 275-287. Dordrecht: Foris.

Martineau, Frances. 1993. Rection forte et rection faible des verbes: 1'ellipse de que en français du Québec et de 1'Ontario. Francophonies d'Amérique 3:79-90.

Nadkarni, Mangesh V. 1975. Bilingualism and syntactic change in Konkani. Language 51:672-83.

Otheguy, Ricardo. 1995. When contact speakers talk, linguistic theory listens. In E. ContiniMorava, \& B. Sussman, Meaning as explanation: Advances in linguistic sign theory, 213242. Berlin: Mouton de Gruyter.

Prince, Ellen. 1992. On syntax in discourse, in language contact situations. In Claire Kramsch \& S. McConnell-Ginet, Text and context: Cross-disciplinary perspectives on language study, 98112. Boston: D.C. Heath.

Silva-Corvalán, Carmen. 1994. Language contact and change: Spanish in Los Angeles. Oxford: Clarendon.

Silva-Corvalán, Carmen. 1998. On borrowing as a mechanism of syntactic change. In A. Schwegler et al., Romance linguistics: Theoretical perspectives, 225-246. Amsterdam: John Benjamins.

Subirats-Rüggeberg, Carlos. 1987. Sentential complementation in Spanish. Amsterdam: John Benjamins.

Thomason, Sarah G. 1986. On establishing external causes of language change. In Soonja Choi et al., Proceedings of the Second Eastern States Conference on Linguistics, 243-251. Columbus: Department of Linguistics, Ohio State University. 
Thomason, Sarah, \& Terence Kaufman. 1988. Language contact, creolization, and genetic linguistics. Berkeley: University of California Press.

Tomasello, Michael. 2003. Constructing a language. A usage-based theory of language acquisition. Cambridge: Harvard University Press.

US Bureau of the Census. 2005. Population Division. Washington, D.C.: US Government.

Wald, Benji. 1983. Referents and topic within and across discourse units: Observations from current vernacular English. In Flora Klein-Andreu, Discourse perspectives on syntax, 91-116. New York: Academic Press.

Weinreich, Uriel. [1953] 1974. Languages in contact, eighth printing. The Hague: Mouton.

Weinreich, Uriel, William Labov \& M. Herzog. 1968. Empirical foundations for a theory of language change. Winifred Lehmann \& Yakov Malkiel, Directions for historical linguistics, 95-195. Austin: University of Texas Press.

Winford, Donald. 2007. Some issues in the study of language contact. Journal of Language Contact, Thema 1:22-39. www.jlc-journal.org. 